\title{
COPING MECHANISM IN THE FACE OF LANDSLIDE HAZARD IN EAST JAVA INDONESIA
}

\author{
Syamsul BACHRI* \\ Universitas Negeri Malang, Faculty of Social Science, Geography Department, Indonesia, e-mail: syamsul.bachri.fis@um.ac.id
}

Sumarmi SUMARMI

Universitas Negeri Malang, Faculty of Social Science, Geography Department, Indonesia, e-mail: sumarmi.fis@um.ac.id

Listyo Yudha IRAWAN

Universitas Negeri Malang, Faculty of Social Science, Geography Department, Indonesia, e-mail: listyo.fis@um.ac.id

Yulius Eka ALDIANTO

Universitas Negeri Malang, Faculty of Social Science, Geography Department, Indonesia, e-mail: yuliusekaaldianto3@gmail.com

Kresno Sastro Bangun UTOMO

Universitas Negeri Malang, Faculty of Social Science, Geography Department, Indonesia, e-mail: krisno.sbu@gmail.com

Aqilah Kusuma WARDHANI

Universitas Negeri Malang, Faculty of Social Science, Geography Department, Indonesia, e-mail: aqilahwardhani@gmail.com

\begin{abstract}
Citation: Bachri, S., Sumarmi, S., Irawan, L.Y., Aldianto, Y.E., Utomo, K.S.B., \& Wardhani, A.K. (2022). COPING MECHANISM IN THE FACE OF LANDSLIDE HAZARD IN EAST JAVA INDONESIA. GeoJournal of Tourism and Geosites, 40(1), 144-149. https://doi.org/10.30892/gtg.40117-813
\end{abstract}

\begin{abstract}
Increasing the number of landslide disasters and their effecting population in Indonesia is crucial to concern and need a solution. A coping mechanism is the strategies of people exposed to disasters and a key to anticipate and prepare and reduce landslide disaster risk. During twenty years, Malang Regency in East Java Province was hit by several landslide disasters, which radically affected both the physical and social environment. This paper aims to investigate coping strategie s by communities facing landslide disaster. The methodology used in this research was divided into three sections: (1) pre-field; (2) fieldwork; and (3) post-field. The survey was initially conducted by mapping physical condition and interview with the key of informants. The research result was analyzed utilizing recorded-transcribed interviews and interpreted according to recurrent themes in the answers. Generally, people have performed different strategies to cope with landslide disasters withi $n$ the study area. The coping mechanisms have been well developing into two categories, such as individual and structural coping mechanisms. This case study indicates that a coping strategy should be taken to reduce landslide disaster risks, such as fostering agriculture protection, properties-housing protection, and reinforcing risk governance to improve landslide disaster management and programs fostering adaptation and resilience.
\end{abstract}

Key words: coping mechanism, landslide, disaster management, East Java, Indonesia

\section{INTRODUCTION}

An increasing number of disaster incidents in several countries significantly impact infrastructure and socialeconomic conditions within the population (Budhathoki et al., 2020). Effective preparedness against a natural disaster is playing an essential role in reducing its impacts (UNISDR, 2015). Better information about how the disaster affects people and their livelihood is a crucial prerequisite to designing effective strategies and guiding the disaster preparedness activities (Fatemi et al., 2017; Shreve et al., 2016). It can be achieved effectively through community engagement (Birkmann et al., 2013). The community's hazard knowledge and coping strategies can elevate disaster management within the area facing disaster problems. According to the basic terminology of coping mechanism, it is referred to as a reaction to the contingencies and processes of impoverishment (Daramola et al., 2016).

It happened after the damage has been incurred, mainly when the loss forces an individual or household below a minimum economic or social threshold. In other terminology, it is also defined as an action to face, survive, protect the physical existence, and recover from a shock or stress situation (Paton et al., 2000). The coping strategy is based on an 'ex-post' action in terms of risk adjustment, which means that a household responds to risky events only after an emergency or crisis occurred (Bachri, 2010). This strategy is appropriately applied in the area, categorized as high landslide vulnerability with low disaster technology mitigation (Calvello et al., 2016; Damm et al., 2013).

According to disaster incident data from BNPB, during twenty years, Malang Regency in East Java Province was hit by several landslide disasters that radically affected both the physical and social environment. The landslide disaster

\footnotetext{
* Corresponding author
} 
holds the third top position in number after the flood (BNPB, 2020). Many landslides triggering factors are found within the study area, such as intrinsic factors and extrinsic factors.

The intrinsic factor is the main factor originating from the condition of the land itself. In contrast, the irrelevant factor is a trigger factor from outside, increasing the potential for landslides (Pamungkas and Sartohadi, 2017). Parameters included in intrinsic factors are topographic conditions, soil material, and geology. Increasing steep slope conditions can lead to greater landslide occurrences since soil stability is getting smaller (Xiong et al., 2019). Meanwhile, extrinsic parameters result from human activity (e.g., the development of residential areas on steep slopes and the construction of roads with slope cuts and improper slope loading), rain, and earthquake activity (Bachri and Shresta, 2010).

Several attempts to anticipate landslides have been made, especially during the emergency response period. Activities have been carried out in the form of (BPBD of Malang Regency, 2020):

Installation of simple buildings to protect landslides on roads

Formulation of strong regulations, especially related to disaster management and disaster risk reduction.

Increasing the commitment of stakeholders, especially the community, is a strategic step to embrace, empower, and increase all major actors in disaster management, starting from the government, society (civil society), and the business world.

However, landslide disaster management does not seem effective. Through this research, we try to figure out the coping strategy applied by the community since the coping strategy condition plays a pivotal role in addressing the landslide disaster problem in the study area. This paper aims to investigate coping strategies by communities facing landslide disaster.

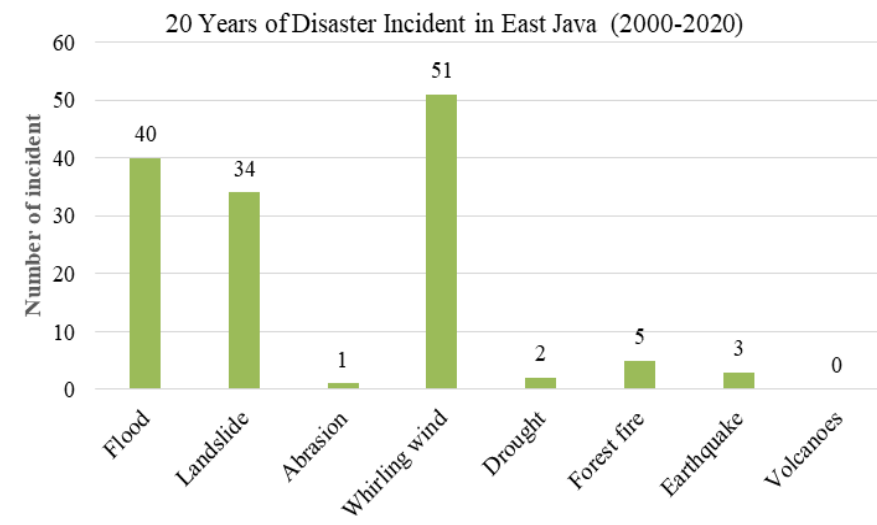

Figure 1. Disaster incidents during 20 years (Source: BNPB, 2020)

\section{METHODS}

The research data collection phase in this research was divided into three parts: first pre- field; continued by fieldwork; and last, is the analysis phase. We did literature review, data preparation, and collection, which involve collecting digital imagery of the study area, thematic map, current local policy document, and landslide data. During fieldwork, we checked the physical and social condition and their validity. We also did interviews with a critical person of the local people as well as local government staff. We interview several people; three regional governments (BPBD and village officer, ten informants). The next step was the analysis phase, which includes analysis of coping mechanisms within the study area. The detailed methodology can be seen below table.

Table 1. Research methodology

\begin{tabular}{|c|l|l|l|}
\hline Processes of research & \multicolumn{1}{|c|}{ Activities } & \multicolumn{1}{c|}{ Purpose/rationale } & \multicolumn{1}{c|}{ Source } \\
\hline \multirow{4}{*}{ Pre field } & Literature review & $\begin{array}{l}\text { Landslide data, socio-economic and } \\
\text { demographic profile, current policy } \\
\text { planning }\end{array}$ & $\begin{array}{l}\text { Journal paper, government report, } \\
\text { newspaper, NGOs report, Research } \\
\text { report. }\end{array}$ \\
\cline { 2 - 4 } & Digital mapping & Administration map, landform map & $\begin{array}{l}\text { Geospatial Information Agency } \\
\text { (BIG), LAPAN }\end{array}$ \\
\hline \multirow{4}{*}{ Fieldwork } & Landslide data checking & Landslide point existing & Fieldwork \\
\cline { 2 - 4 } & Documentation of current policy & Disaster management policy & Intuition visitation, interview \\
\cline { 2 - 4 } & $\begin{array}{l}\text { Interview with a key informant } \\
\text { and local government officer }\end{array}$ & $\begin{array}{l}\text { People behaviour and government } \\
\text { policy }\end{array}$ & Interview \\
\hline \multirow{4}{*}{ Post field } & Coping strategy analysis & Coping mechanism & Interview \\
\cline { 2 - 4 } & Socio, economic and policy analysis & Social profile & Document and interview \\
\cline { 2 - 4 } & $\begin{array}{l}\text { Development of coping } \\
\text { mechanism practice model }\end{array}$ & Model of coping mechanism & Coping mechanism analysis \\
\hline
\end{tabular}

This research takes Bantur, Donomulyo, Gedangan, and sumbermanjing sub-district in East Java Province as study areas (Figure 2). During January-June 2020, interviews were conducted with a representative of local communities and government officials in four sub-districts to investigate local knowledge related to hazard, current disaster management policy, and coping strategies to landslide risk. Informants were village officers, farmers, and authorized staff from BPBD Malang district. The content of the interview starts with the question of landslide hazard understanding, risk perception, and hazard knowledge, socio-demographic, life value, and current disaster management policy. The informants were encouraged to answer freely, and all interviews were conducted in Indonesia and the Javanese language. Interviews were recorded by the audio recorder and then transcript into the interview script notula.

\section{RESULTS AND DISCUSSION}

To get a comprehensive understanding of the coping mechanism within the study area, we present our findings in three-part: 1) understanding the physical environment, 2) socio-economic context, and 3) coping strategies applied by the community in the following section. 


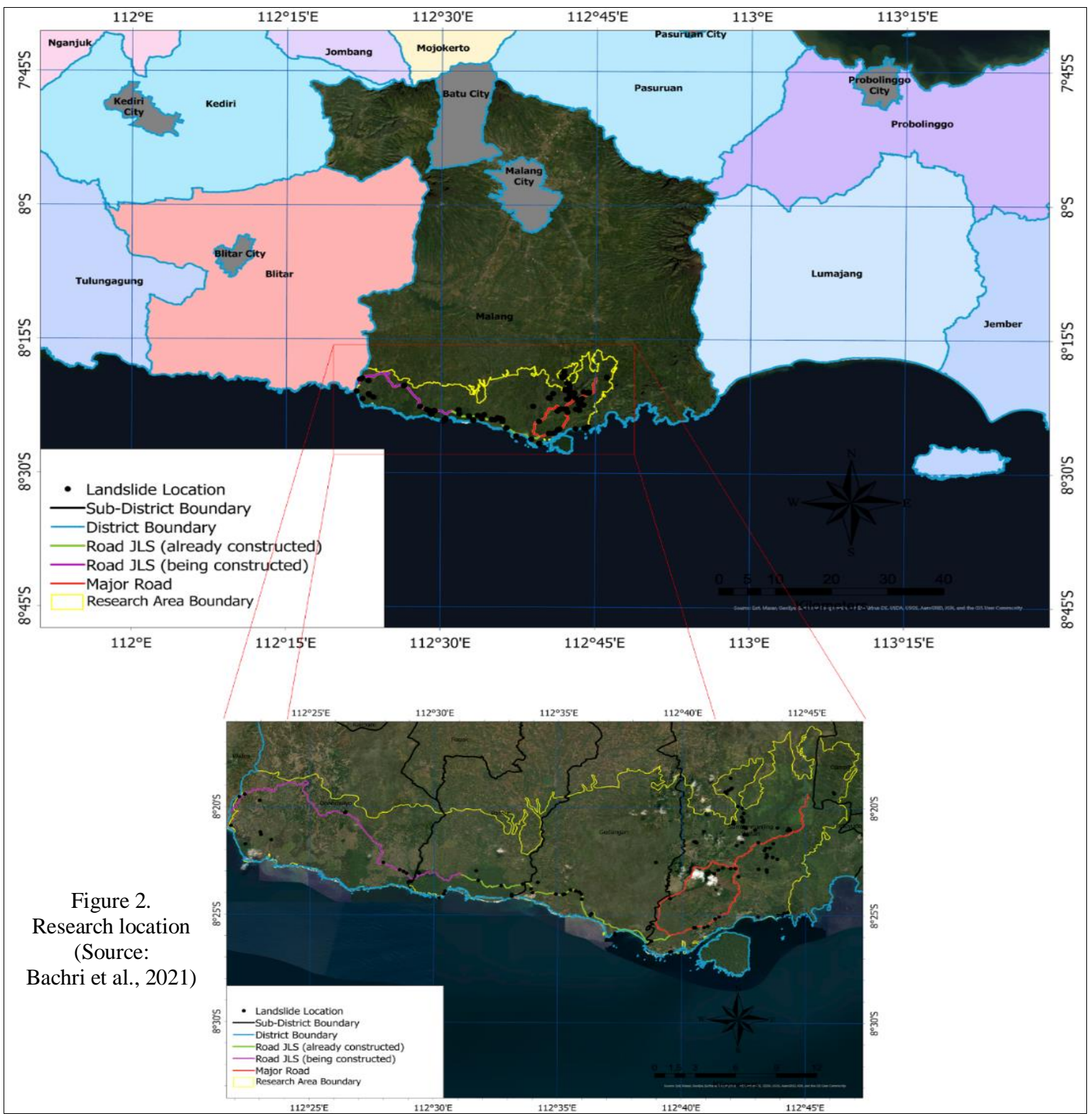

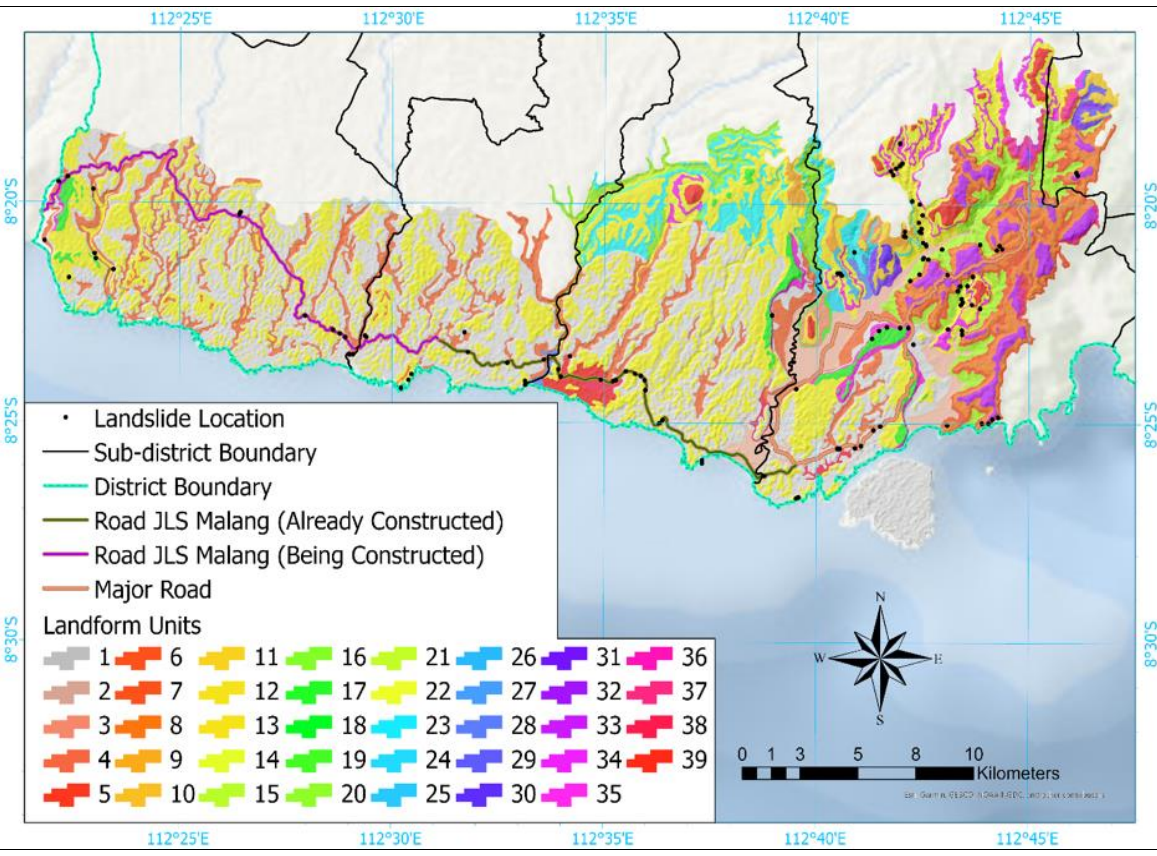

Figure 3. Landform map of the study area (Bachri et al., 2021)
Toward a physical environment of the study area

Malang regency in East Java is shared by 38 districts, with a total population of 2,619,975 (BPS of Malang Regency, 2020). With a total area of about $3,530.65 \mathrm{~km}^{2}$, the topography is dominated by the plateau, surrounded by several mountains, particularly within the study area. Most of the stratigraphy situations covered by limestone (Kendeng Mountains) have high porosity (BPS of Malang Regency, 2020). Furthermore, the rainfall intensity at the average rainfall is ranging from $0 \mathrm{~mm}$ to $602 \mathrm{~mm}$ (BPS of Malang Regency, 2020). Based on the landform configuration, the study area is dominated by hilly and strong erosion processes (Bachri et al., 2021). 
Detail of landform identification within the study area can be seen in below Table 2. Due to above condition (Table 2), Malang regency categorized as landslide hazards prone area as seen as below figure (Figure 4).

Table 2. Landform unit of the study area

\begin{tabular}{|c|c|c|c|}
\hline Unit Code & Symbol & Landform Units & $\operatorname{Area}\left(\mathbf{k m}^{2}\right)$ \\
\hline 1 & $\mathrm{U} / 3 / \mathrm{SSE} / 1$ & Middle Slope of the Wonosari Formation- significantly eroded & 132.59 \\
\hline 2 & $\mathrm{P} / 5 / \mathrm{D} / 4$ & Colluvium Foot Slope and Alluvium deposition & 14.44 \\
\hline 3 & $\mathrm{H} / 3 / \mathrm{M} / 2$ & Middle Slope of the Hills Nampol Formation-moderate erosion & 1.80 \\
\hline 4 & $\mathrm{U} / 4 / \mathrm{SSE} / 1$ & Lower Slopes of the Wonosari Formation-significantly eroded & 40.74 \\
\hline 5 & $\mathrm{H} / 1 / \mathrm{SSE} / 5$ & Hilltops of the Mandalika Formation - significantly eroded & 3.67 \\
\hline 6 & $\mathrm{H} / 3 / \mathrm{SSE} / 5$ & Middle Slope of Tuff Hills the Mandalika Formation- significantly eroded & 12.48 \\
\hline 7 & $\mathrm{H} / 2 / \mathrm{M} / 5$ & Upper Slope of the Tuff Hills the Mandalika Formation -a moderate erosion of & 17.35 \\
\hline 8 & $\mathrm{H} / 1 / \mathrm{SSE} / 2$ & Hilltops of the Nampol Formation-significantly eroded & 2.23 \\
\hline 9 & $\mathrm{H} / 2 / \mathrm{SSE} / 3$ & Upper Slopes of the Wuni Formation-significantly eroded & 2.09 \\
\hline 10 & $\mathrm{H} / 2 / \mathrm{SSE} / 2$ & Upper Slope of the Nampol Formation-significantly eroded & 3.15 \\
\hline 11 & $\mathrm{U} / 4 / \mathrm{SSE} / 2$ & Lower Slope of the Nampol Formation- significantly eroded & 3.74 \\
\hline 12 & $\mathrm{U} / 2 / \mathrm{M} / 2$ & Upper Slope of the Nampol Formation-moderately eroded & 11.22 \\
\hline 13 & $\mathrm{U} / 2 / \mathrm{M} / 1$ & Upper Slope of the Wonosari Formation-moderately eroded & 86.68 \\
\hline 14 & $\mathrm{U} / 5 / \mathrm{D} / 1$ & Colluvium Foot Slope and Alluvium Wonosari Formation & 1.29 \\
\hline 15 & $\mathrm{U} / 5 / \mathrm{D} / 2$ & Colluvium Foot Slope and Alluvium Nampol Formation & 2.08 \\
\hline 16 & $\mathrm{U} / 4 / \mathrm{SSE} / 2$ & Lower Slope of the Nampol Formation-significantly eroded & 8.62 \\
\hline 17 & $\mathrm{U} / 2 / \mathrm{SE} / 1$ & Hilltops of the Wonosari Formation-slightly eroded & 5.45 \\
\hline 18 & $\mathrm{U} / 1 / \mathrm{SE} / 2$ & Hilltops of the Nampol Formation-slightly eroded & 0.34 \\
\hline 19 & $\mathrm{H} / 4 / \mathrm{M} / 2$ & Lower Slope of the Hills of Nampol Formation -moderately eroded & 0.47 \\
\hline 20 & $\mathrm{H} / 4 / \mathrm{SSE} / 5$ & Lower Slope of the Tuff Mandalika Formation- significantly eroded & 13.98 \\
\hline 21 & $\mathrm{H} / 2 / \mathrm{SSE} / 5$ & Upper Slope of the Mandalika Formation - significantly eroded & 6.62 \\
\hline 22 & $\mathrm{H} / 4 / \mathrm{SSE} / 5$ & Lower Slopes of the Mandalika Formation - significantly eroded & 11.43 \\
\hline 23 & $\mathrm{U} / 3 / \mathrm{M} / 2$ & Middle Slope of the Nampol Formation - moderately eroded & 11.38 \\
\hline 24 & $\mathrm{H} / 4 / \mathrm{SSE} / 2$ & Lower Slope of the Nampol Formation - significantly eroded & 2.20 \\
\hline 25 & $\mathrm{H} / 3 / \mathrm{SSE} / 2$ & Middle Slope of Nampol Formation - significantly eroded & 1.41 \\
\hline 26 & $\mathrm{U} / 5 / \mathrm{M} / 5$ & Colluvium Foot Slope and Alluvium of Mandalika Formation - moderately eroded & 0.94 \\
\hline 27 & $\mathrm{H} / 1 / \mathrm{SE} / 5$ & Hilltops of the Mandalika Formation - Slightly eroded & 0.46 \\
\hline 28 & $\mathrm{U} / 5 / \mathrm{D} / 2$ & Colluvium Foot Slope and Alluvium of Nampol Formation - deposited & 1.25 \\
\hline 29 & $\mathrm{H} / 3 / \mathrm{M} / 3$ & Middle Slope of the Wuni Formation - moderately eroded & 1.35 \\
\hline 30 & $\mathrm{H} / 1 / \mathrm{SSE} / 3$ & Hilltops of the Wuni Formation - significantly eroded & 0.49 \\
\hline 31 & $\mathrm{H} / 4 / \mathrm{SSE} / 3$ & Lower Slopes of the Wuni Formation - significantly eroded & 1.39 \\
\hline 32 & $\mathrm{H} / 1 / \mathrm{SSE} / 5$ & Hilltops of the Mandalika Formation - significantly eroded & 10.75 \\
\hline 33 & $\mathrm{H} / 3 / \mathrm{SSE} / 5$ & Middle Slope of the Mandalika Formation - significantly eroded & 7.19 \\
\hline 34 & $\mathrm{H} / 4 / \mathrm{M} / 3$ & Lower Slope of the Hills - moderately eroded & 0.18 \\
\hline 35 & $\mathrm{H} / 5 / \mathrm{D} / 5$ & Colonial Foot Slope and Alluvium of Mandalika Formation - deposited & 1.05 \\
\hline 36 & $\mathrm{U} / 2 / \mathrm{SSE} / 1$ & Upper Slope of the Wonosari Formation - significantly eroded & 3.42 \\
\hline 37 & $\mathrm{H} / 2 / \mathrm{SSE} / 5$ & Upper Slope of the Tuff Mandalika Formation -significantly eroded & 2.24 \\
\hline 38 & $\mathrm{U} / 4 / \mathrm{D} / 1$ & Lower Slope of Wonosari Formation- deposited & 1.79 \\
\hline 39 & $\mathrm{U} / 3 / \mathrm{D} / 1$ & Middle Slope of Wonosari Formation-deposited & 2.64 \\
\hline
\end{tabular}

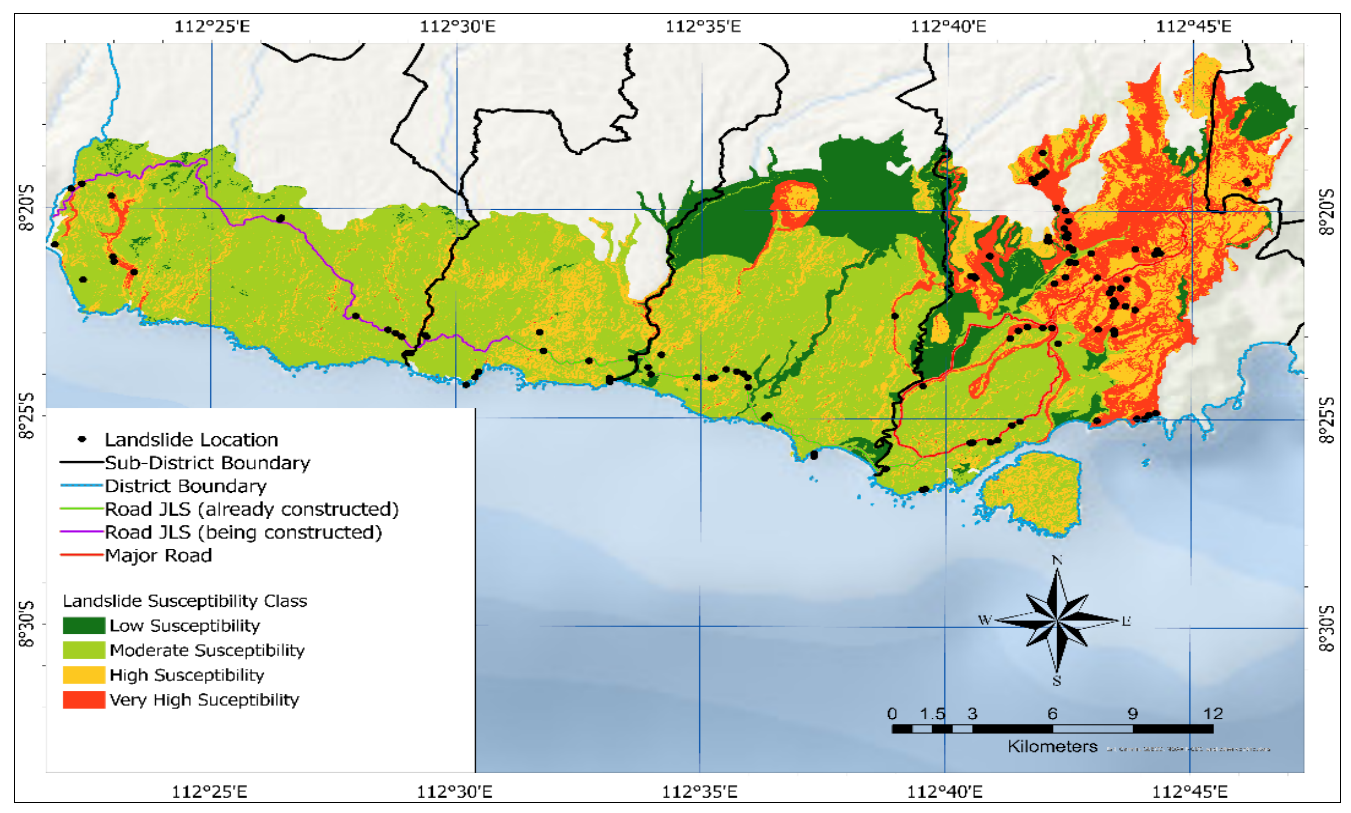

Figure 4. Landslide susceptibility map (Bachri et al., 2021) 


\section{Social context}

We can adapt information related to population, age, sex, occupation, etc., based on demographic data profiles (Lindell and Hwang, 2008). The total population of Malang district is 2,619,975 (BPS of Malang Regency, 2020). Data showed the number of females $1,302,991$ is lower than male 1,316,984. In addition, in line with working status, it is noted that more than $75 \%$ of the head of household within the area is engaged with an occupation, particularly as farmer and labor. This study was based on the classification of age respondent and its members to FAO classification. It consists of three categories; young age, working-age, and senior age. The age of 0-15 is categorized as a young age, and the age group of $15-60$ is considered working age. Moreover, the age group above 60 is categorizing as senior group age. The community is significantly working-age dominated. The level of education is important in understanding educational conditions within the study area (Azadi et al., 2019). Data showed that the domination of community education was in junior - high school levels. It is mostly due to the difficulty of access and the availability of money. People choose to have less education rather than spend their limited money on education activity. The economic factor is one of the obstacles to enhance higher education levels in this area. It contradicts general common knowledge since education is an indicator of improving people's awareness of their economic condition (Ullah et al., 2015). In addition, it is also stated that education level will influence the community in many factors, such as job opportunities and people's behavior. Educated people will have a chance to get a good occupation along with a good opportunity. In this study, we tried to capture how the education level can influence people's behavior, particularly their coping mechanism activity in facing landslide hazards.

This study showed that education level has indirect relation with people activity within the study area. They relatively know what they should do to reduce the landslide hazard impact. This is because they can access information from many sources, e.g., the internet. Another factor that we want to discuss is community occupation since it is important in natural resource utilization (Guha-Sapir et al., 2013). We found that farmer occupation was dominant among others in the study area. They are categorized as low and medium-income receivers. The sources of low income and medium income are mainly from agriculture, labor activities, and commerce.

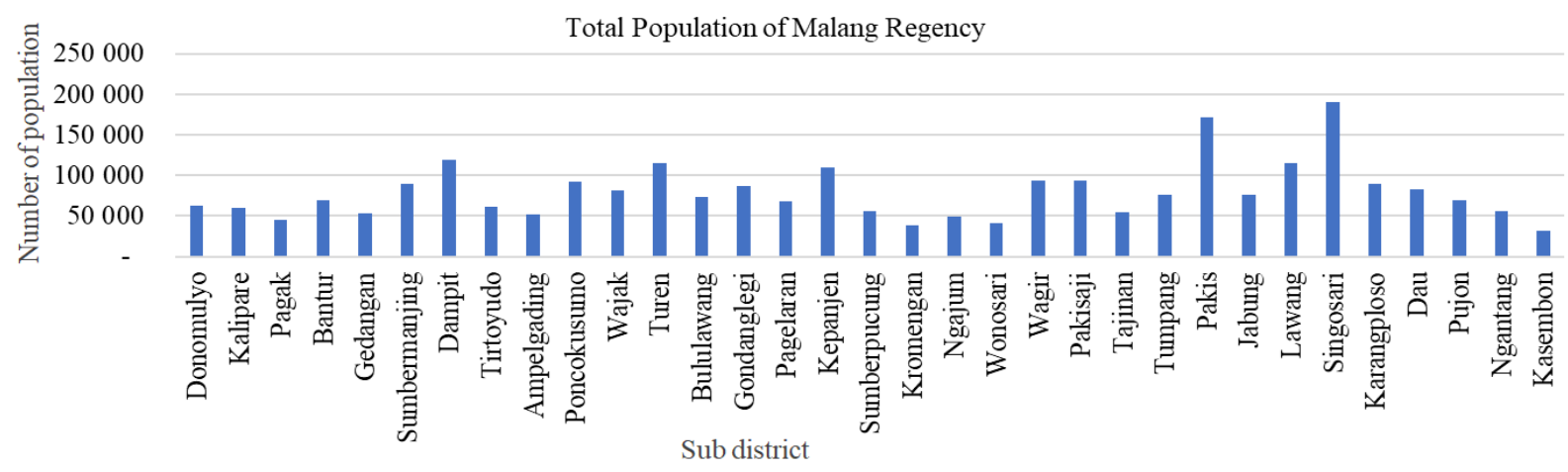

Figure 5. Population data within the study area (Source: BPS, 2020)

\section{Coping strategies}

Many factors affect coping strategies, such as physical and social factors (Xu et al., 2018; Zhou et al., 2014). Physical factors such as the structure of the building and contents are a dominant factor within the study area. Social factors such as income and education level, and access information were the main factors influencing communities' coping strategies. People with more income will have more opportunities to do proper coping strategies, particularly in building houses with strong construction. They also can create a wall barrier to deal with a landslide in their cropland. Furthermore, people with more access to information in the study area take more action with recent technology to prevent their properties from landslide hazard. In this study, we found that people were doing coping mechanisms based on three reasons: economic, social, and natural resources condition. It is linked to each other, financial situation, social network, and practical action (Bachri, 2010). In addition, this study also found the two types of coping mechanisms adopted by the community: individual coping mechanisms and structural coping mechanisms.

In the individual coping mechanism, they prefer to protect their natural resources assets comparing with others. It's rational since most of them are engaged with the farming occupation. In addition, they also try to protect their house from landslide effects. However, it is done by a community with higher income and good access to information. According to our analysis, the study area's coping mechanism was dependent upon various factors. Occupation, income, access to information, and education level were the factors that influence people to act on coping mechanisms. Furthermore, through literature review and interviews with local government, we found that structural coping mechanisms already develop through many programs. The local institutions did some programs in educating community-related about landslide disaster in the study area. It formed through training and focus group discussion. However, the program is not fully implemented due to some obstacles, such as a fund.

Our last result shows that coping strategies in the study area are linked to risks. People at risk or vulnerable will have more effort to survive and protect their assets from disaster (Slovic, 2000).

\section{CONCLUSION}

The study found that people have performed different strategies to cope with landslide disasters within the study 
area. The coping mechanisms have been well developing into two categories, such as individual and structural coping mechanisms. Factors such as income, level of education, and access to information were the community's main factors to perform coping activities.

This study also indicates that a coping strategy should be taken to reduce landslide disaster risks, such as fostering agriculture protection, properties-housing protection, and reinforcing risk governance to improve landslide disaster management and programs fostering adaptation and resilience.

\section{Acknowledgement}

This study was supported by Faculty of Social Sciences Universitas Negeri Malang through "hibah publikasi” program 2021. The author would like to thank all contributors for their assistance during data collection in Malang District.

\section{REFERENCES}

Azadi, Y., Yazdanpanah, M., \& Mahmoudi, H. (2019). Understanding smallholder farmers' adaptation behaviors through climate change beliefs, risk perception, trust, and psychological distance: Evidence from wheat growers in Iran. Journal of Environmental Management, 250, 109456. https://doi.org/10.1016/j.jenvman.2019.109456

Bachri, S. (2010). Mapping landslide hazard and developing land capability based management practice in Central Java. Asian Institute of Technology, Thailand.

Bachri, S., \& Shresta, R.P. (2010). Landslide hazard assessment using analytic hierarchy processing (AHP) and geographic information system in Kaligesing mountain area of Central Java Province Indonesia. 5th Annual International Workshop \& Expo on Sumatra Tsunami Disaster \& Recovery 2010, 9, 107-112.

Bachri, S., Shresta, R.P., Sumarmi, S., Yulianto, F., Utomo K.S.B., \& Aldianto, Y.E. (2021). Mapping landform and landslide susceptibility using remote sensing, GIS and field observation in the southern cross road, Malang regency, East Java, Indonesia. Geosciences, 11(1):4. https://doi.org/10.3390/geosciences11010004

Birkmann, J., Cardona, O.D., Carreño, M.L., Barbat, A.H., Pelling, M., Schneiderbauer, S., Kienberger, S., Keiler, M., Alexander, D., Zeil, P., \& Welle, T. (2013). Framing vulnerability, risk and societal responses: The MOVE framework. Natural Hazards, 67, 193211. https://doi.org/10.1007/s11069-013-0558-5

Budhathoki, N.K., Paton, D.A. Lassa, J., \& Zander, K.K. (2020). Assessing farmers' preparedness to cope with the impacts of multiple climate change-related hazards in the Terai lowlands of Nepal. International Journal of Disaster Risk Reduction, 49(May), 101656. https://doi.org/10.1016/j.ijdrr.2020.101656

Calvello, M., Papa, M.N., Pratschke, J., \& Nacchia Crescenzo, M. (2016). Landslide risk perception: a case study in Southern Italy. Landslides, 13, 349-360. https://doi.org/10.1007/s10346-015-0572-7

Damm, A., Eberhard, K., Sendzimir, J., \& Patt, A. (2013). Perception of landslides risk and responsibility: A case study in eastern Styria, Austria. Natural Hazards, 69, 165-183. https://doi.org/10.1007/s11069-013-0694-y

Daramola, A.Y., Oni, O.T., Ogundele, O., \& Adesanya, A. (2016). Adaptive capacity and coping response strategies to natural disasters: A study in Nigeria. International Journal of Disaster Risk Reduction, 15, 132-147. https://doi.org/10.1016/j.ijdrr.2016.01.007

Fatemi, F., Ardalan, A., Aguirre, B., Mansouri, N., \& Mohammadfam, I. (2017). Social vulnerability indicators in disasters: Findings from a systematic review. International Journal of Disaster Risk Reduction, 22, 219-227. https://doi.org/10.1016/j.ijdrr.2016.09.006

Guha-Sapir, D., Santos, I., \& Borde, A. (2013). The Economic Impacts of Natural Disasters. Oxford University Press.

Lindell, M.K., \& Hwang, S.N. (2008). Households' perceived personal risk and responses in a multihazard environment. Risk Analysis, 28(2), 539-556. https://doi.org/10.1111/j.1539-6924.2008.01032.x

Pamungkas, Z., \& Sartohadi, J. (2017). Slope Stability Study in Landslide Area in Magelang District Bompon Sub-watershed. Jurnal Bumi Indonesia, 6(2), 1-10. http://repositorio.unan.edu.ni/2986/1/5624.pdf

Paton, D., Smith, L., \& Violanti, J. (2000). Disaster response: Risk, vulnerability and resilience. Disaster Prevention and Management: An International Journal, 9(3), 173-179. https://doi.org/10.1108/09653560010335068

Shreve, C., Begg, C., Fordham, M., \& Müller, A. (2016). Operationalizing risk perception and preparedness behavior research for a multi-hazard context. Environmental Hazards, 15(3), 227-245. https://doi.org/10.1080/17477891.2016.1176887

Slovic, P. (2000). Risk, society, and policy series. In The perception of risk. Earthscan Publications.

Ullah, R., Shivakoti, G.P., \& Ali, G. (2015). Factors Effecting Farmers' Risk Attitude and Risk Perceptions: The Case of Khyber Pakhtunkhwa, Pakistan. International Journal of Disaster Risk Reduction, 13, 151-157. https://doi.org/10.1016/j.ijdrr.2015.05.005

Xiong, J., Sun, M., Zhang, H., Cheng, W., Yang, Y., Sun, M., Cao, Y., \& Wang, J. (2019). Application of the Levenburg-Marquardt back propagation neural network approach for landslide risk assessments. Natural Hazards and Earth System Sciences, 19(3), 629-653. https://doi.org/10.5194/nhess-19-629-2019

Xu, D., Peng, L., Liu, S., \& Wang, X. (2018). Influences of Risk Perception and Sense of Place on Landslide Disaster Preparedness in Southwestern China. International Journal of Disaster Risk Science, 9, 167-180. https://doi.org/10.1007/s13753-018-0170-0

Zhou, Y., Li, N., Wu, W., Wu, J., \& Shi, P. (2014). Local spatial and temporal factors influencing population and societal vulnerability to natural disasters. Risk Analysis, 34(4), 614-639. https://doi.org/10.1111/risa.12193

*** BNPB. (2020). Trends in Disasters in the Last 10 Years in Indonesia. https://bnpb.cloud/dibi/

*** BPBD of Malang Regency. (2020). Report The Results of Interviews.

*** BPS of Malang Regency. (2020). Malang Regency In Figures 2020. BPS-Statistics of Malang Regency.

*** UNISDR. (2015). Sendai Framework for Disaster Risk Reduction 2015-2030. United Nations International Strategy on Disaster Reduction. http://www.unisdr.org/files/43291_sendaiframeworkfordrren.pdf

Article history: Received: 01.02.2021 Revised: 10.11.2021 Accepted: 12.01.2022 Available online: 02.02.2022 